\title{
The Application of Inquiry Learning to Increase The Activity and Critical Thinking Skill
}

\author{
W. C. Ratri, M.V Roesminingsih, T. Suyanto \\ Universitas Negeri Surabaya \\ Surabaya, Indonesia \\ wulancahyaningratri@gmail.com
}

\begin{abstract}
This research aims to describe the application of inquiry learning by utilizing the environment to increase the activity and critical thinking skill of the students in the fourthgrade social sciences lesson at SDN Bangkingan II/442 Surabaya.

This research is a classroom action research using a procedure belonging to Kemmis and Taggart. The study consisted of three cycles, each cycle consists of four stages: planning, execution, observation, and reflection. The subject of this study is the fourth-grade students SDN Bangkingan II/442. Data collection techniques in this study using observation sheets and test students critical thinking skills.

As for the results of the study research include student activity at the end of the cycle is $82,82 \%$ and result of critical thinking skill of student $80,43 \%$, it can be concluded that the application of inquiry learning by utilizing the environment can increase the activity and critical thinking skill of students on social sciences in the fourth grade at SDN Bangkingan II/442 Surabaya.
\end{abstract}

Keywords: Inquiry; Activities; Critical Thinking.

\section{INTRODUCTION}

The inquiry is a learning that can give simulation for students to think critical, careful, and systematic to solve the problem [1]. The inquiry is meant to develop thinking skill at a high level for students is thinking critical not only in the understanding of learning material. Levelled equations, graphics, and tables are not prescribed, although the various table text styles are provided [2]. The formatter will need to create these components, incorporating the applicable criteria that follow.

One of the education purposes is to build critical thinking of students [3]. Education should touch good potential in inner and also students' competence.

In real life, students are very needed critical thinking skill, someone is required to have the capability to select carefully on the face the different situation to understand a concept of the problem which is presented. Critical thinking is high level involves intellectual, making a conclusion, knowing idea, formulating, verifying power sources, and making an induction, taking a conclusion, and assumption [4].

Social sciences are one of learning material in Elementary School which is contacted with how to interact and socialize between human in society environment. Social science is a subject to learn about human interaction and all aspects of society [5]. Students are human in society must have knowledge supplies and skill in interaction with others. A human who aware with right and duty, respect one each other and get harmony life.

One of material in social science learning in fourth class is human economic activation material, on those material discussion students are hoped to activate and know the connection in real life, on those material students, are required to think critical, have curiosity, inquiry and exercise skill in social life. This material teaches students to understand the facts of life and how to think critical to formulate and conclude a problem in real life.

The important understanding concept in learning process influences on making a decision, attitude and how to solve the problem [6]. Understanding knowledge contents is a requirement to have a good argument [7]. The fact is students only memorize the concept but less in how to use the concept to make a decision in real life, more over students are less in critical thinking to make a decision and formulate it.

From interviewing the teacher of fourth grade in SDN Bangkingan II/442 Surabaya, the result of social sciences learning in the economic subject is not satisfied. When the students are given questions which need critical thinking skill to decide and conclude the problem, that $70 \%$ data of the fourth-grade students' got the result, and the result was less than minimum mastery criteria (75). From 23 students, only six students' who got a score of more than 75, meanwhile 17 students' got a score less than 75 . Students who got $95=1$ students, $80=3$ students, $75=2$ students, and $<75=17$ students. From the observation result which is done in SDN Bangkingan II/442 Surabaya while learning process, the condition was not conducive, still conventional, the teacher did learning process by using lecture method and only used handbook as the source of learning, sometimes students' were invited to discuss but the students' looked past. They prefer staying on the desk, kept silent, listened, wrote and memorized so the learning process became monotonous. When the teacher gave question in oral which needed students' to identify the problem, only 5 students' looked active to answer meanwhile the others were still pasif, the students' didn't understand economic social problem in society interaction, this showed that the students' were not used to practice to think critically.

Some materials in social sciences learning is often talked how human fulfil their daily need, students' are rated still don't 
have skill in critical thinking, students' memorize and can mention the definition from human economic activity but students' are still unskilled in delivering opinion based on certain proves, submit and verify hypotheses throw investigation, gather, process, arrange the report, and also communicate investigation results in oral and written.

The learning process doesn't show critical skill, students' more often study in theory but rarely in direct practising in real life, that's why students' can't develop optimally in thinking, students' potential doesn't improve, actually in social sciences learning need skill which can support students' to develop their thinking to make a decision in their life.

Based on critical thinking skill in the fourth grade of SDN Bangkingan II/442 in subtheme of the uniqueness if my hometown still less, the activity in class is also passive. We need interesting and innovate learning strategy, contextual and appropriate with students' thinking level. Series of strategy must be developed from based education in order to make students' get skill and capability in scientific learning sector, so it can be applied in very aspect in daily need [8].

Based on that problem, one of learning model that can be used by the teacher to make better on grade and learning quality on students' by applying inquiry learning model. Inquiry learning is the series of learning activity which focuses on the critical learning process and analytical to search and finds the answer to the problem which faced [9].

Media and materials are needed in learning which can be got from around. Someone who aware with environment must be supplied with scientific knowledge to make a decision, aware from effect and able to analyze the problem and also offer the solution to solve the problem in the natural and social environment [10]. The environment is everything out of the individual, every kind of environments can be sources and learning material, it can support the learning process for students' [11].

From those explanations, we know that the environment is important in students' growth and development, nature can be a learning media to make a meaningful learning experience for students'. The environment can be used to be a learning source for every subject learning because it can be found everywhere.

After doing observation, one of the main potentials in SDN Bangkingan II/442 is in the village, exactly in Lakarsantri subdistrict in the limit of Surabaya and Gresik. The researcher knows that many nature potentials around the school, SDN Bangkingan II/442 is surrounded by fields, husbandries, gardens, and bamboo forest that can be used for learning sources especially in an economic subject in social science learning. Positive education value can be got from out of education in the village and also has a relation between affective value and cognitive value [12]. Students' can be guided by the teacher to formulate, find make a hypothesis, get the information, and also conclude a problem from economical activity in the school environment. From the school data, most of the SDN Bangkingan II/442 students' parents as the farmers and self-employed that can be sourced in the inquiry learning process. By getting direct information from the sources, hopefully, students' can be more skilful in formulating, making hypotheses, proving, and concluding a problem in economical activity in the school environment. Students' are hoped to be more critical in thinking, so they have to interact with the school environment not only stay in class.

Based on description background, stimulate the researcher to make that problem as the research material for classroom action research by title the application of inquiry to increase the activity and critical thinking skill of the students' in the fourth-grade social sciences lesson at SDN Bangkingan II/442 Surabaya.

\section{RESEARCH METHOD}

The kind of research is classroom action research. The research used this kind of research to look for and find the solution of the students, problems in class. In this solution the teacher as the research that's why he/she knows the weakness in the learning process.

Inquiry learning process can use environment in research, that's focused in the learning activity and students' critical thinking skill. The research is done by the steps of planning, doing, observing and reflexing with different material in the same based competence, was done in a cycle until an increase in the learning activity and also critical thinking skill indictorachived.

The subject of the classroom action research was the fourth-grade students' of SDN Bangkingan II/442 Surabaya in academic year 2017/2018 which has 23 students, 17 students' were boys and 6 students' were girls. The optimal subject was based on the fourth-grade students' that able to think logic to make and conclude a problem in the learning process.

In classroom action research, data were submitted to answer the research question is about being active in the learning process and critical thinking skill on students' is economic learning material concept in social science. In this research, data collecting technique was done by two ways to observe and a critical thinking test.

This research is used research instrument by using students' observation sheets, critical thinking evaluation sheet and validation instrument test which is contained os syllabus validation sheet, lesson plan, students' activity validation sheet, quiz validation test sheets, learning material validation sheets, observation validation sheets of students' activity.

In this research, data analysis technique used in ways which are data analysis technique for students' activity and critical thinking skill. Then, observation data result was analyzed by using the formula :

$$
\mathrm{P}=\frac{f}{n} \times 100 \%
$$

Students' critical thinking skill improvement while teaching-learning process, through inquiry learning implementation was calculated by using students' critical thinking skill percentage with the formula : 
Final Score $=$ totaly score which is obtained $\times 100 \%[14]$

\section{RESULT AND DISCUSSION}

\section{Expediency/ properness}

In this action research, learning administration which is used is: syllabus, lesson plan, students' activity sheet, students' material learning and students' critical thinking skill sheet. Before it is used, sets of equipment were validated by people who expert on those filed.

All of the learning equipment and research instrument, in general, can be categorized into less revision and proper to use in research.

\section{Research Result Description}

Inquiry learning which was using the environment in this research was done in three cycles. Learning material in the $1^{\text {st }}$ cycle was human economical activity by doing observation in rice production process and live interview with a farmer around the school. The material on the $2^{\text {nd }}$ cycle still discussed the human economical activity. Changed of lesson plan only on early activity, how teacher to motived students'. On the $3^{\text {rd }}$ cycle, the student still discussed human economical activity was using the environment in this learning process.

While learning process, teacher colleague input observation sheets. Observation sheet is used to know students' activity development in the learning process.

The summary students' activity observation result in $1^{\text {st }}$, $2^{\text {nd }}, 3^{\text {rd }}$ cycles based on all of the observed aspects can be seen in table 2.

TABLE 2. STUDENTS' ACTIVITY OBSERVATION RESULT

\begin{tabular}{|c|c|c|c|}
\hline \multirow[t]{2}{*}{ Kind of activity } & \multicolumn{3}{|c|}{ Observation every cycle } \\
\hline & $1^{\text {st }}$ cycle & $2^{\text {nd }}$ cycle & $3^{\text {rd }}$ cycle \\
\hline Visual Activities & 149 & 183 & 180 \\
\hline Oral Activities & 149 & 186 & 196 \\
\hline Listening Activities & 151 & 184 & 197 \\
\hline Writing Activities & 144 & 175 & 191 \\
\hline Drawing Activities & 144 & 179 & 196 \\
\hline Motor Activities & 140 & 174 & 192 \\
\hline Mental Activities & 138 & 174 & 187 \\
\hline Emotional Activities & 137 & 173 & 184 \\
\hline Total & 1.152 & 1.428 & 1.523 \\
\hline Percentage & $62,61 \%$ & $77,61 \%$ & $82,77 \%$ \\
\hline
\end{tabular}

The following is the students' critical thinking skill result on every cycle based on achievement indicator.

TABLE 3. CRITICAL THINKING SKILL INDICATOR RESULT

\begin{tabular}{|c|c|c|c|c|}
\hline \multirow{2}{*}{ Kind of activity } & \multicolumn{3}{|c|}{ Observation } & \multirow{2}{*}{ Total } \\
\cline { 2 - 4 } & $\begin{array}{c}\mathbf{1}^{\text {st }} \\
\text { cycle }\end{array}$ & $\begin{array}{c}\mathbf{2}^{\text {nd }} \\
\text { cycle }\end{array}$ & $\begin{array}{c}\mathbf{3}^{\text {rd }} \\
\text { cycle }\end{array}$ & \\
\hline Elementary clarification & 426 & 441 & 467 & 1.334 \\
\hline Basic for the decision & 420 & 433 & 456 & 1.309 \\
\hline Interference & 431 & 451 & 471 & 1.353 \\
\hline Advanced clarification & 406 & 433 & 461 & 1.300 \\
\hline Supposition and integration & 400 & 432 & 455 & 1.287 \\
\hline Total & 2.083 & 2.190 & 2.310 & 6.583 \\
\hline Presentage & $72 \%$ & $76 \%$ & $80 \%$ & $76 \%$ \\
\hline
\end{tabular}

Based on table 3, every critical thinking skill indicator which was specified, always be seen increase start from $1^{\text {st }}, 2^{\text {nd }}$, and $3^{\text {rd }}$ cycle. It can be known that there was increasing on students' critical thinking skill on $1^{\text {st }}$ cycle was $72 \%$, the $2^{\text {nd }}$ cycle was $76 \%$, and the $3^{\text {rd }}$ cycle was $80 \%$.

\section{CONCLUSION}

Based on the analysis, research result and discussion about inquiry learning implementation by using the environment to increase activity and students' critical thinking can be done appropriately with the plan on the lesson plan and run goodly. It can be concluded as follows.

1. Inquiry learning implementation by using environment utilization can increase students' learning activity on social science learning with subtheme the uniqueness of our resident. The increasing can be seen in the increasing of students' learning activity on $1^{\text {st }}-3^{\text {rd }}$ cycle which can be reached by achievement indicator which was specified with percentage $83 \%$. The research can be said successful if students' learning activity reached achievement $\geq 80 \%$.

2. Inquiry learning implementation by using environment utilization can increase students' critical thinking skill in social science with subtheme the uniqueness of our resident on the fourth grade of SDN Bangkingan II/442 Surabaya. Students' critical thinking skill was increased significantly. That is proved by the increasing of students' critical thinking skill result on $3^{\text {rd }}$ cycle reached $83 \%$. Those increasing can be seen by the achievement indicator on the $3^{\text {rd }}$ cycle was students' critical thinking skill percentage that showed students' in the learning process increase on minimum $80 \%$.

\section{SUGGESTION}

Based on the research result which was done by inquiry learning implementation by using the environment to increase activity and students' critical thinking skill on social science on the fourth grade of SDN Bangkingan II/442 Surabaya, the suggestion which is given by the researcher is.

1. The teacher uses inquiry learning by using environment utilization on social science cause based on research, uses inquiry learning by using environment can increase students' learning activity.

2. The teacher uses inquiry learning by using environment utilization on social science based on research, inquiry learning can increase students' critical thinking skill.

3. It is needed the continued research on inquiry learning implementation by using environment utilization an material and other contexts.

\section{References}

[1] Hartono, R, Ragam model mengajar yang mudah diterima murid, Yogyakarta: Diva Press,pp.61. 2013

[2] Kardi, Soeparman, Model pembelajaran langsung inkuiri sains teknologi dan masyarakat, Surabaya: Universitas Negeri Surabaya, pp.23. 2013 
[3] Hashemi, Seyed Ahmad, The use of critical thinking in social science textbooks of high school: a field study of Fars province in Iran, International Journal of Instruction, 4 (1). 1-16. pp.3. 2011

[4] Kitot. Awg Kasmurie Awg, Ahmad. Abdul Razak, and Seman. Ahmad Ali, The effectiveness of inquiry teaching in enhancing students' critical thinking, Procedia Social and Behavioral Sciences 7(C), 2010, 64-273. Advance online publication.Doi:10.1016/j.sbspro. 10.037. pp.5. 2010.

[5] Sapriya, Pendidikan IPS konsep dan pembelajaran, , Bandung: PT Remaja Rosdakarya, pp.20. 2009,

[6] Trianto, "Mendesain model pembelajaran inovatif progresif," Prenada media Group, Jakarta, pp.89. 2009.

[7] Tsai. Pei Ying, Chen. Sufen, Chang. Por-Huey, Chang. Wen-Hua, Effects of prompting critical reading of science news on seventh graders' cognitive achievement, International Journal of Environmental \& Science Education. 8 (1). 85-107, pp.4. 2013

[8] Diaz. Luis Del Espino, The teaching of the experimental sciences in primary education through a methodology by inquiry: learning difficulties and pedagogical guidelines, International Journal Of Environmental \& Science Education. 12 (8). 1-6, pp.2. 2017

[9] Sanjaya. Wina, Strategi pembelajaran berorientasi standar proses pendidikan, Jakarta: Prenadamedia Group, pp.196. 2006

[10] Derman. Aysegul, Sahin. Elvan, dan Hacieminoglu, Does outdoor education make any difference in environmental literacy of pre-service classroom teachers? International Journal Of Environmental \& Science Education, 11 (15). 8491-8506, pp.3. 2016,

[11] Rohman. Muhammad \& Amri. Sofan, Strategi \& desain pengembangan sistem pembelajaran, Jakarta: Prestasi Pustakaraya, pp.86. 2013

[12] Smeds. Pia, Joronen. Eila, Kurppa. Sirpa, \& Vieraankivi. Marja Liisa, Rural camp school eco learn-outdoor education in rural setting, International Journal of Environmental \& Science Education. 6 (3). $267-$ 291, pp.21. 2011,

[13] Sudijono. Anas, Pengantar statistik pendidikan, Jakarta: PT Raja Grafindo Persada, pp. 43. 2009,

[14] Rohani. Ahmad, Pengelolaan pengajaran, Jakarta: PT Rineka Cipta, pp.194. 2004 